\title{
Comparative Research on Entrepreneurial Management and Traditional Management
}

\author{
Yue Hao \\ College of Business Administration, Jilin Engineering Normal University, Changchun City, China
}

18792044@qq.com

\begin{abstract}
Keywords: Venture management; Traditional intelligent management; Enterprise strategic management; Comparative study; Difference
\end{abstract}

\begin{abstract}
Sustained growth and development of enterprises is closely related to entrepreneurship and effective entrepreneurial management is needed. Entrepreneurial management is the basic way to the long-term stable development and expansion of the enterprise, this is an important content of modern enterprise management. Entrepreneurial management mainly carries out strategic management by standing in the perspective of entrepreneurial interpretation, this is also a general way of carrying out strategic and general management from modern enterprise development and management for modern enterprise development, making "entrepreneurship" the important content of enterprise strategic management, and becoming the core of enterprise development. Therefore, this article will start from the concept of entrepreneurial management to explore the difference between entrepreneurial management and traditional management, and then put forward the way of modern enterprise strategy management.
\end{abstract}

\section{Introduction}

Sustained growth and development of enterprises is closely related to entrepreneurship and effective entrepreneurial management is needed. Entrepreneurial management is the basic way to the long-term stable development and expansion of enterprise, this is an important content of modern enterprise management. Entrepreneurial management mainly carries out strategic management by standing in the perspective of entrepreneurial interpretation. This is a new discipline which is intersected by strategic management and entrepreneurship raised by Stevenson and Jarillo in 1990 [1]. This is also a general way of carrying out strategic and general management from modern enterprise development and management for modern enterprise development, making "entrepreneurship" the important content of enterprise strategic management, and becoming the core of enterprise development. There are significant differences between entrepreneurial management and traditional management. These differences are also an important advantage that entrepreneurial management becomes the core of enterprise management. We will discuss the difference of entrepreneurial management and traditional management next, put forward the way of modern enterprise strategy management.

\section{The Difference between Entrepreneurial Management and Traditional Management}

Generally speaking, entrepreneurial management is a combination, a organic system and a process that some factors effect and promote the enterprise to keep growing and improving. By using sociology, management, economics, psychology, entrepreneurial management can research the inherent law of entrepreneurship, mainly include the activities of creating the new career and the innovative behaviors in different stages and levels. Its characteristics mainly reflect in innovation, advancement, risk-taking, team cooperation and realization of stable growth and continuous development by constantly explore and identify opportunities, and constantly adapt to uncertain, complex, dynamic and changing environment. The core is the dynamic and guidance. Entrepreneurial dynamic is that the entrepreneurship of enterprise should keep continuing in the process of corporate and environmental transformation, and reinforce in different entrepreneurial chances. The guidance mainly refers to that 
we need to search for opportunities, identify opportunities, use and develop opportunities, in order to achieve our own economic benefits continuously. The difference between entrepreneurial management and traditional management are shown in Table 1.

Table 1 The difference between entrepreneurial management and traditional management

\begin{tabular}{|c|c|c|}
\hline Difference & Entrepreneurial Management & Traditional Management \\
\hline Background & $\begin{array}{l}\text { A new economy era in which industrial } \\
\text { society transform to consumer society }\end{array}$ & Large industrial machinery era \\
\hline Supervisor Mode & $\begin{array}{l}\text { The management of product upgrades, } \\
\text { updates, new business, new product } \\
\text { research and development and the } \\
\text { intellectual property management }\end{array}$ & $\begin{array}{l}\text { Technique-oriented Management } \\
\text { [4], the main factors are: } \\
\text { Specialization, automation, scale } \\
\text { operation, big market, a large } \\
\text { number of manufacturing, } \\
\text { engineering, design, research and } \\
\text { development }\end{array}$ \\
\hline Research Object & $\begin{array}{l}\text { The theory of entrepreneurial management } \\
\text { mainly studies the activities of the } \\
\text { enterprise's new enterprise and the } \\
\text { innovative behavior of the enterprise in } \\
\text { different stages and different levels [5]. } \\
\text { The main purpose of the enterprise is to } \\
\text { cultivate excellent entrepreneurs, its } \\
\text { research objects or objects not only include } \\
\text { large enterprises, large companies, but } \\
\text { also including small enterprises, private } \\
\text { enterprises and so on. }\end{array}$ & $\begin{array}{l}\text { Traditional management theory bias } \\
\text { to the existing large company as the } \\
\text { object of study tend to existing } \\
\text { enterprises to provide risk aversion, } \\
\text { enhance the effectiveness of } \\
\text { management methods, the } \\
\text { knowledge, the skill, the main } \\
\text { purpose is to cultivate the excellent } \\
\text { professional managers. }\end{array}$ \\
\hline Study Scopes & $\begin{array}{l}\text { Starting point of entrepreneurial } \\
\text { management lies in the sustainable growth } \\
\text { and stable development of enterprises, the } \\
\text { core issue of entrepreneurship } \\
\text { management lies in its dynamic and } \\
\text { opportunity oriented [6]. Opportunity } \\
\text { oriented mainly refers to the enterprise's } \\
\text { entrepreneurial activities can not only be } \\
\text { limited to their existing resources, it must } \\
\text { continue to explore opportunities, identify } \\
\text { opportunities, use and development } \\
\text { opportunities, so as to achieve their own } \\
\text { success. }\end{array}$ & $\begin{array}{l}\text { The starting point of the traditional } \\
\text { management is to improve the } \\
\text { efficiency and efficiency of } \\
\text { enterprises. }\end{array}$ \\
\hline Content System & $\begin{array}{l}\text { Entrepreneurial management system } \\
\text { includes personal knowledge preparation } \\
\text { and with the opportunity to integrate and } \\
\text { team spirit and modern enterprise } \\
\text { management concept of integration, } \\
\text { integration of enterprise resources with the } \\
\text { company's future development strategy, } \\
\text { the enterprise new business, new projects } \\
\text { and the characteristics of the times and the } \\
\text { needs of the times fusion. }\end{array}$ & $\begin{array}{l}\text { Traditional management mainly } \\
\text { through planning, organization, } \\
\text { leadership and control to achieve } \\
\text { production and management. }\end{array}$ \\
\hline
\end{tabular}


Differences in Strategic Orientation. Traditional management embodies is a kind of resource oriented management. Because in the enterprise management, the pressure it faces mainly comes from enterprise external contract, strict planning system, the enterprise shareholder within the organization performance appraisal, etc. Therefore, in the traditional management activities, its pattern is "one resource do one thing," The goal is to achieve the effective allocation of resources, to promote the business benefit [7]. In entrepreneurial management, it is a kind of chance-oriented management. Because enterprise's environment is rapidly changing, complex and uncertain. The emergence of a variety of business opportunities is the most important resources of the enterprise development and growth. So, the detection, identification, development and utilization of all kinds of opportunities are the core of entrepreneurial management, the most basic strategy of enterprise development.

Differences in Resource and Acquisition and Control. In entrepreneurship, entrepreneurial thought is an important concept. In all kinds of complicated and changeable environment, the enterprise should have advanced cognition, be ready to develop and use a variety of business opportunities. In entrepreneurial management, therefore, because the limitation of enterprise's ability to control the environment and lacing of prediction in the need of resource, temporary resources must be taken to remedy, like temporary rent, besides the effective use of existing resources. Therefore, the access and control of enterprise resource is not a kind of ownership, but a kind of ownership acquisition and control in entrepreneurial management [8]. In traditional management, in order to avoid all kinds of risk and to improve its efficiency, enterprise often take a formal financial budget and plan design purchase a large number of savings, by means liking inventory continually to reduce risk. in the process of its management, enterprise will access to resources as much as possible to reduce the risk and cost.

Differences in Organizational Structure and Organizational Learning. In entrepreneurial management, because resources don't have to be done by property possession, it can be done by resource control. Therefore, the enterprise organization structure does not require the clear power and responsibility, it emphases on the autonomy of the enterprise staff. The organization structure is a kind of flat, informal organization structure. But, in the traditional management, the management often need to regulate the clear power and responsibility. This organization structure is often a bureaucratic hierarchy system [9]. At the same time, in the aspect of organizational learning, the differences between Entrepreneurial management and traditional management lie in the management attitude of organizational learning. Entrepreneurial management tend to consider that the truth today may not be true tomorrow. So enterprise management not only should learn all kinds of existing enterprise management theory, but also need to forget and update. In traditional management, the management is used to institutionalize ground to carry on the operation and management. They often interest on management system and management theory, not new knowledge and new ideas.

Differences between Two Different Stages. As mentioned, traditional management prefer to regard the existing large companies as the research objects. But the objects of Entrepreneurial management include large companies and small businesses, private enterprises, etc. Actually regardless of the object of study, enterprise business process can be divided into two stages, finding opportunities ; developing and using opportunities. Finding opportunities includes the analysis and refine of the opportunity. Developing and using opportunities mainly includes the integration and utilization of new resources. Its first stage is the entrepreneurial management process, and the second stage is the traditional management process. This is called "stage theory" [10].

\section{For the Future of the Enterprise Management, Academia Has a Large Controversy}

For enterprise management in the future, there is a lot of controversy in the academic field, there is an alternative to say, that is, the business management to replace the traditional functions of management, there is a fusion of said, that is, the integration of entrepreneurial management and traditional functional management. The author is inclined to the integration and development of business management and the traditional function management. P. Davidsson of business management and 
traditional management were compared. He believes that entrepreneurship includes two processes: one is the discovery process, including the first opportunity to discover and refine the opportunity. The two is the development and utilization of the process, is to solve the problem of resource acquisition and integration of the new resources. Business management mainly in the first process, second process belongs to the traditional management.

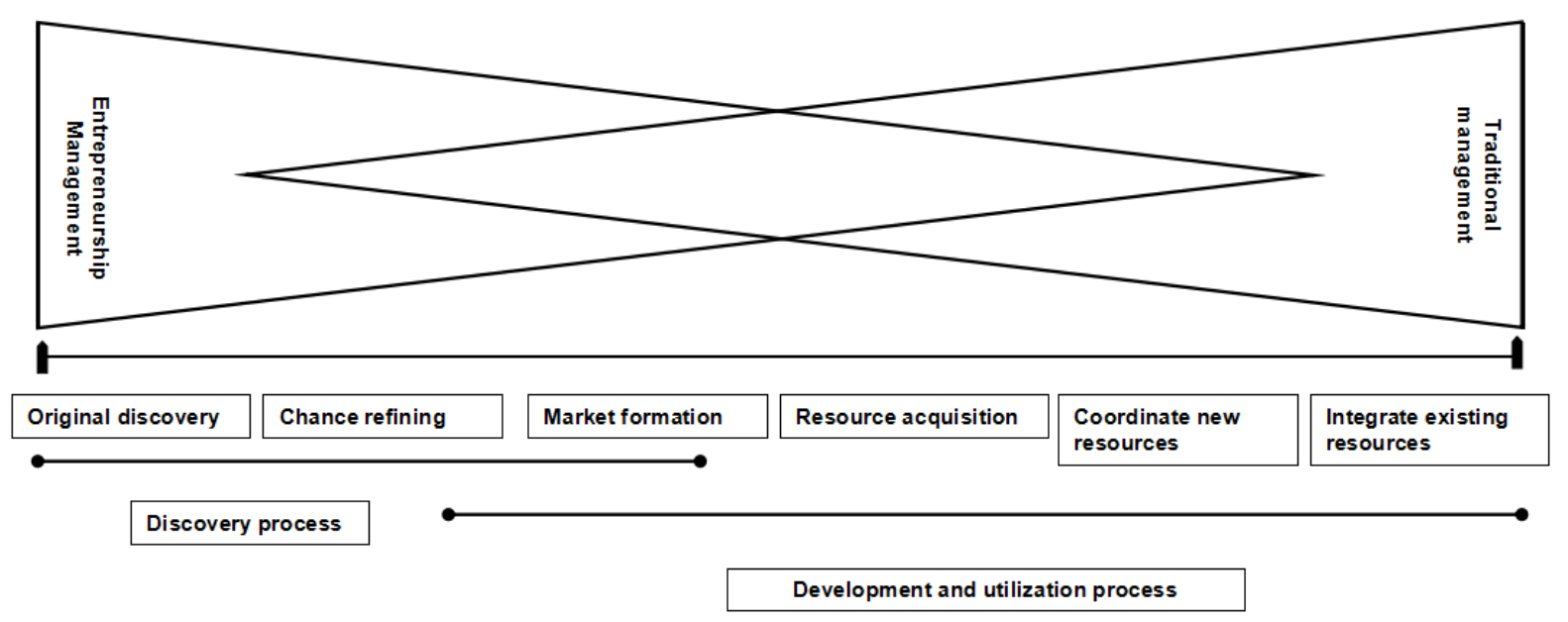

Figure 1. The relationship between entrepreneurial management and traditional management

The integration of entrepreneurial management and traditional function management is the best management logic of modern enterprise. First, both inside and outside the enterprise is full of a lot of radical change; the competitive advantage of an enterprise is no longer a relatively stable, but the changing; enterprises must seize the existing market in a certain environment, and in some other environment create new markets; this requires who currently rely mainly on traditional administrative management of enterprise must change the management mode, pay attention to business management, and promote the integration of business management and administrative management. Second, entrepreneurial functions focus on the long-term performance of the enterprise, while the traditional management functions focus on short-term control needs. As the different stages of enterprise growth are faced with different tasks, the combination of entrepreneurial functions and traditional management functions to better reflect the needs of growth. In prime phase and stable phase, due to the two functions with the best, enterprises not only to achieve the appropriate flexibility, but also to ensure the controllability of moderate, the enterprise has obtained the unity of the short-term efficiency and long-term effect of the.

\section{Conclusion}

Entrepreneurial management and traditional intelligent management difference is mainly manifested in two aspects of theory and practice: theory, differences in entrepreneurial management and traditional management performance in different background, different management paradigm, the research object is different, the starting point of the study of different, the content system of different aspects; differences in practice, the differences in entrepreneurial management and traditional management mainly differences in strategic orientation, resource acquisition and control, organizational structure and organizational learning differences, two different stages of differences. According to the development direction of enterprise strategic management, the author thinks that the integration of business management and traditional management is an important means of modern enterprise management. 


\section{References}

[1] M. Luo: Development of Paradigms in Management Theory, Southwestern University of Finance and Economics Press, Chengdu, 2013.

[2] B.Sue and M.C. Daniel: Entrepreneurship Management, Pearson Group, Taiwan 2013.

[3] J. Qin: Management Review, Vol. 24 (2012) No.9, p.94-102.

[4] A. Issac, R. Zhao et al: Enterprise Life Cycle M, China Social Science Press, Beijing 2013.

[5] D. Peter, B. Wang, G.H. Shen: Organization of Management, Shanghai University of Finance and Economics Press, Shanghai 2011.

[6] R.A. Chris: Organizational Learning, Renmin University of China Press, Beijing 2004.

[7] B. Shooner and A.H. Catherine: Edge Competition, Mechanical Industry Press, Beijing 2001.

[8] B. Eyre: Social Research Methods, Huaxia Press, Beijing 2005.

[9] M. Zhang and Z.G. Hu: Social Scientist, Vol. 28 (2013) No.9, p.64-66+74.

[10]F. Zhang and F.X. Yao: Academic Journal of Jinyang, Vol. 26 (2006) No.6, p.53-57. 